\title{
Land use conversion in humid tropics influences soil carbon stocks and forms
}

\author{
Viti Oso and B.K. Rajashekhar Rao*
}

Department of Agriculture, The PNG University of Technology, Private Mail Bag, Lae 411, Morobe Province, Papua New Guinea. *Corresponding author: rajashekhar.rao@pnguot.ac.pg

\begin{abstract}
Land use change is one of the most important drivers of excessive carbon dioxide $\left(\mathrm{CO}_{2}\right)$ emission and is partly responsible for global warming. Certain land use systems promote the sequestering of excessive carbon from the atmosphere to the soil, while other systems accelerate $\mathrm{C}$ loss through emissions. Herein, a study was conducted to evaluate the soil $\mathrm{C}$ forms and carbon stocks in the soils of three land use systems (a pasture, field crop and cocoa plantation) that were developed following the conversion of grasslands in the humid lowland landscape of Papua New Guinea. A remarkable decline $(\mathrm{P}<0.001)$ in the total $\mathrm{C}$ concentration of the grassland soils was observed due to land conversion into either field crops (44\%) or a cocoa plantation (28\%). Among the land use systems, organic $\mathrm{C}$ was the dominant pool (78.1-86.9\%) compared to inorganic $\mathrm{C}$, which only contributed $13.1 \%-21.9 \%$ to the total $\mathrm{C}$ stock. The soil organic $\mathrm{C}$ stocks were present in the following order: grassland $\left(217.9 \mathrm{Mg} \mathrm{ha}^{-1}\right)>$ pasture $\left(207.6 \mathrm{Mg} \mathrm{ha}^{-1}\right)>$ cocoa plantation $\left(139.4 \mathrm{Mg} \mathrm{ha}^{-1}\right)>$ field crops $\left(131.6 \mathrm{Mg} \mathrm{ha}^{-1}\right)$. The results of this study indicated that the conversion of grasslands to other land use systems (such as a cocoa plantation and field crops) could lead to the depletion of soil C stocks.
\end{abstract}

Keywords: Climate change, inorganic C, loss-on-ignition method, organic C, sequestration, soil fertility

\section{Introduction}

The excessive release of carbon dioxide $\left(\mathrm{CO}_{2}\right)$ from fossilized organic compounds (fossil fuel) and land use changes has created an imbalance in the atmospheric and soil carbon (C) stocks, which has caused a rise in global temperatures (IPCC, 2013; Munoz et al., 2016). It has been predicted that by 2100 , the global temperature will increase by $5.8^{\circ} \mathrm{C}$. The interest in soil
$\mathrm{C}$ has greatly increased in recent years because terrestrial organic carbon can be a factor in understanding the effect of $\mathrm{C}$ emissions on global climate change (Maraseni et al., 2008). Agricultural soils and organic matter, in particular, can be sources or sinks of atmospheric $\mathrm{CO}_{2}$. In general, soils represent the largest stock of C $(\sim 1500 \mathrm{Pg})$, which is approximately twice 
the amount held in the atmosphere and three times the amount contained in terrestrial vegetation. Currently, soils are subject to varying degrees of direct or indirect human disturbance, and land use change is one of the most important human activities leading to losses of $\mathrm{C}$ and nutrients from the soil (Smith et al., 2016). Land use systems play a vital role in stabilizing $\mathrm{CO}_{2}$ levels in the atmosphere and increasing the $\mathrm{C}$ sink potentials of soils (Kumar and Nair, 2011). Land use systems, together with other climatic and edaphic factors, affect $\mathrm{C}$ storage within soil and vegetation. Land misuse (the improper allocation of land without considering the capability of the land) and poor soil management practices can cause depletions in the organic $\mathrm{C}$ stock in the soil through emissions to the atmosphere (Lal, 2004; Gelaw et al., 2014). The type of land use system determines the organic $\mathrm{C}$ levels and pool sizes in the soil by affecting the amount and quality of the litter input, litter decomposition rates and organic matter stabilization processes. Data on the effects of land use changes on soil organic and inorganic $\mathrm{C}$ stocks are needed to identify viable land use systems for $\mathrm{C}$ sequestration. Information on the organic matter content of different soil types and the resulting ecosystem services, such as $\mathrm{C}$ and nutrient storage, need further research in contrasting pedoclimatic contexts (Rumpel et al., 2015). Carbon stock measurements are also required by an international agreement between 192 countries of the world that have joined to form a treaty. The United Nations Framework Convention on Climate Change (UNFCCC) was formed to address global warming by stabilizing the greenhouse gas concentrations in the atmosphere (Hairiah et al., 2010).

Carbon stock refers to the quantity of $\mathrm{C}$ in a pool, reservoir or system that has the capacity to accumulate or release carbon (Hairiah et al., 2010). Soil C exists primarily in three chemical forms, although few attempts have been made to fractionate $\mathrm{C}$ based on its faunal oxidation potential or the ecosystem services it renders (Grandy and Robertson, 2007; Berreto et al., 2011). The chemical components of soil $\mathrm{C}$ are primarily elemental C (e.g., charcoal, graphite and soot) from geological or biomass burning sources, inorganic $\mathrm{C}$ that is derived from geologic or soil mineral sources, such as carbonates (e.g., calcite and dolomite), and organic $\mathrm{C}$ from the natural decomposition of plants and animals (Goodrick et al., 2015). Several methods are available for assessing soil $\mathrm{C}$ stocks; dry combustion analyzers are the most widely used. However, more cost-effective, simple, and dependable loss-on-ignition methods are occasionally used (Wang et al., 2012).

In Papua New Guinea (PNG) and the South Pacific region, very little information is available on the soil organic C storage capacities of soils under different land use systems. Grasslands make up $>2.5 \%$ of the total land area of PNG, and the current subsistence food gardens have been developed from either former open grasslands or degraded forests (Shearman et al., 2009). The purpose of this study was to determine the $\mathrm{C}$ stock and distribution pattern following the conversion of grassland into three new land use systems in the humid lowland region of PNG. The new information is predicted to help land managers and policy makers make land management decisions. To achieve these goals, the soil inorganic $\mathrm{C}$, organic $\mathrm{C}$ and total $\mathrm{C}$ stocks in grasslands, pasture lands, field/annual crops and cocoa (Theobromae cocoa)-based agroforestry systems were measured at three soil depths $(0-10,10-$ 20 and $20-30 \mathrm{~cm})$.

\section{Materials and Methods}

\subsection{Study location}

The study on the soil C stocks was conducted in four important land use systems nested in an experimental farm situated at the Papua New Guinea University of 
Technology. Geographically, the study area is located between $6^{\circ} 41^{\prime} \mathrm{S}$ and $146^{\circ} 98$ ' $\mathrm{E}$ at an elevation of 65 masl. The climate of the area is classified as lowland humid tropics with an average temperature of 26.3 ${ }^{\circ} \mathrm{C}$ and mean annual precipitation of $\sim 400 \mathrm{~cm}$. The farm has an area of approximately $39 \mathrm{ha}$. The soils of the farm are derived from alluvial deposits with negligible slopes. The soils are classified as sandy, isohyperthermic, Typic Tropofluvents (Soil Taxonomy) or Eutric Fluvisols (World Reference Base). The topsoils are slightly gravelly and have sandy loam or sandy textures. The stratified subsoils have fine gravel at irregular depths (Hartemink et al., 2000).

The landscape for the study (a farm) was selected to minimize the possible effects of geological factors on soil C stocks. In this landscape, different land uses were imposed on the relatively uniform soil.

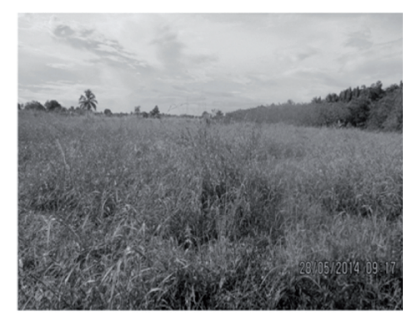

Grassland

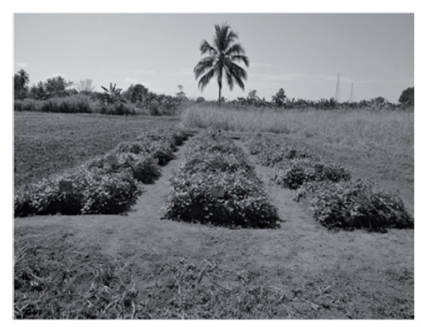

Field crops
The farm land was under native grassland for decades before being converted to other land uses: a pasture that is regularly grazed by small ruminants, an annual field crop block and a cocoa plantation block (Figure 1). Each land use system within the landscape had an area greater than $1.5 \mathrm{ha}$. A rapid appraisal of the cropping history and the various crop management operations collected from the historical records of the farm revealed that the land was under these agricultural and horticultural cropping systems for 28 years, beginning in 1976. A summary of the management practices of the studied land use systems is presented in Table 1. Soil samples were collected from the different land use systems in August 2014 for the fractionation and quantification of the $\mathrm{C}$ stocks, and the results were compared using a paired-site approach.

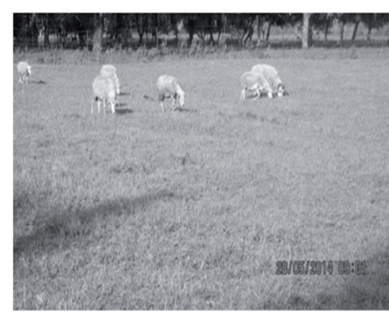

Pasture land

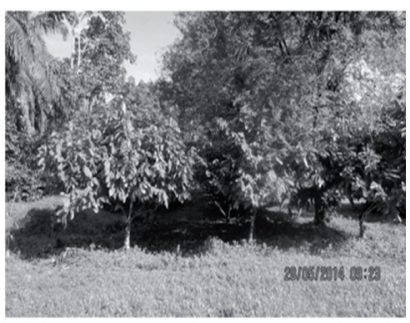

Cocoa plantation

Figure 1. Different land use systems used in the study. 
Table 1. Important features of the land use systems selected for this study

\begin{tabular}{ll}
\hline Land use systems & Land use history and vegetation \\
\hline Grassland & The unused land area was covered with Imperata cylindrica (kunai grass), \\
& Saccharum spontaneum (cow grass), Rottboellia cochinchinesis (Itch grass) \\
& and other minor vegetation species. No tillage was done except for the \\
& occasional vegetation slashing and burning. \\
Pasture land & A grazing paddock was established in 1976 with native herbage. The livestock \\
& grazing area has been used for grazing by small ruminants, mostly goats and \\
& sheep. \\
& An experimental block of the grassland was used for the field crop \\
& experiments. Multiple annual crops have been grown over time. Historically, \\
& corn (Zea mays), taro (Colocasia esculenta), sweet potato (Ipomoea batatas), \\
& peanuts (Arachis hypogaea), mung beans (Vigna radiata), upland rice (Oriza \\
& sativa), aibika (Abelmoshus manihot), cassava (Manihot esculenta) and yams \\
& (Dioscorea alata; D. Esculenta and D. rotundata) have been grown in this \\
& block. Short periods of land fallowing (less than six months) were common. \\
& Synthetic chemical fertilizers (urea, triple superphosphate, and muriate of \\
& potash) and complex fertilizer mixtures were used in this block along with the \\
& occasional use of poultry manure. Weedicides, such as glyphosate with \\
& gramoxone, were the most popular herbicides. Land preparation for each \\
& experiment utilized tractor-drawn plows. At the time of the soil sample \\
& collection for the current study, the land was under a sweet potato crop \\
& (Ipomoea batatas). \\
The cocoa plants have been Trinitario and Criolo types since 1976. The site \\
was replanted in 2005 with cocoa at a spacing of $3 \mathrm{~m} \times 3 \mathrm{~m}$ and intercropped \\
with gliricidia (Gliricidia sepium) at a spacing of $24 \mathrm{~m} \times 24 \mathrm{~m}$. \\
\hline
\end{tabular}

\subsection{Soil sampling}

From the four land use systems, soil samples were collected from three soil depths, 0-10, 10-20 and 20-30 $\mathrm{cm}$, using soil core cutters, as described by Blake and Hartge (1986). In each land use type, three $8 \mathrm{~m} \times 8 \mathrm{~m}$ transects were identified to serve as replicates. From each transect, 10 simple random samples were collected and composited. The sampling was performed depthwise, resulting in a total of 36 soil samples (3 depths $\times 3$ replications $\times 4$ land use systems). The composite soil samples in the cocoa plantation were collected between rows that were approximately $1 \mathrm{~m}$ away from the base of the cocoa plants.

\subsection{Soil analysis}

In the laboratory, the soil cores were oven dried for $72 \mathrm{~h}$ at $105{ }^{\circ} \mathrm{C}$, and the weights were recorded. The bulk density $\left(\mathrm{g} \mathrm{cm}^{-3}\right)$ was calculated as the oven-dried 
weights of the soil cores divided by the volume of the soil cores (Blake and Hartge, 1986). To analyze the soil organic carbon and inorganic carbon concentrations, the soil samples were crushed to a very fine powder with a mortar and pestle and sieved through a $0.18 \mathrm{~mm}$ sieve. Identifiable crop residue materials, such as root fragments and stones, were removed and discarded during sieving.

The soil organic and inorganic carbon concentrations $\left(\mathrm{g} \mathrm{kg}^{-1}\right)$ were analyzed using the loss-on-ignition method (Wang et al., 2012). Briefly, approximately
$5 \mathrm{~g}$ of the soil sample was weighed and placed in a crucible. The crucible contents were heated in a muffle furnace (Scientific Equipment Manufacturers Pty Ltd, model \# 202c) for $12 \mathrm{~h}$ at $105^{\circ} \mathrm{C}$ to remove any moisture from the samples. The moisture-free samples were combusted again at $375^{\circ} \mathrm{C}$ for $17 \mathrm{~h}$, cooled for 2 $\mathrm{h}$ and weighed. Later, the soil residue in the crucibles was combusted in the muffle furnace at $800{ }^{\circ} \mathrm{C}$ for 12 $\mathrm{h}$, cooled for $2 \mathrm{~h}$ and reweighed. The following formulae were used to calculate the soil organic matter and inorganic carbon in grams per kilograms $\left(\mathrm{g} \mathrm{kg}^{-1}\right)$.

SOClor $\left(\mathrm{g} \mathrm{kg}^{-1}\right)=\left[\left(\right.\right.$ Weight $105^{\circ} \mathrm{C}-$ Weight $375^{\circ} \mathrm{C} /$ Weight $\left.\left.105^{\circ} \mathrm{C}\right) \times 1000\right] / 1.724---------(1)$

SIClor $\left(\mathrm{g} \mathrm{kg}^{-1}\right)=\left(\right.$ Weight $375^{\circ} \mathrm{C}-$ Weight $800^{\circ} \mathrm{C} /$ Weight $\left.105^{\circ} \mathrm{C}\right) \times 0.273 \times 1000$

where SOCLor is the soil organic C and SICLor is the soil inorganic $\mathrm{C}$ content determined using the loss-onignition method. The organic matter content was converted to organic $\mathrm{C}$ using a factor of 1.724 assuming $58 \% \mathrm{C}$ in the organic matter. A conversion factor of 0.273 in equation (2) was applied to convert the mass of carbon dioxide $\left(\mathrm{CO}_{2}\right)$ to the mass of $\mathrm{C}$. The size of the $\mathrm{C}$ stock in each land use system to a depth of 30 $\mathrm{cm}$ was calculated in $\mathrm{Mg} \mathrm{ha}^{-1}$ as the sum $\left(\sum\right)$ of the individual $\mathrm{C}$ fractions $\left(\mathrm{g} \mathrm{kg}^{-1}\right) \times$ bulk density $\left(\mathrm{g} \mathrm{cm}^{-3}\right)$ $\times$ depth of the soil (m).

\subsection{Statistical analysis}

The soil variables were analyzed using a factorial analysis of variance (ANOVA) using Statistix Version 8.1 software (Analytical Software, Tallahassee, FL, USA). The land use system and soil depth were considered as the fixed factors. When the F-test was significant $(\mathrm{P}<0.05)$, a post hoc, least significant difference test was performed to separate the means.

\section{Results}

3.1. Effect of the land use system and soil depth on the bulk density of the soil

The bulk density (BD) values differed significantly $(\mathrm{P}<0.001)$ in the studied land use systems (Figure 2). The conversion of the grassland vegetated soil into a pasture for small ruminants and an annual field significantly increased the bulk density by $\sim 10 \%$ each. At the same time, the conversation of the grasslands $\left(1.28 \mathrm{~g} \mathrm{~cm}^{-3}\right)$ into cocoa plantations $\left(1.24 \mathrm{~g} \mathrm{~cm}^{-3}\right)$ slightly decreased the bulk density. The bulk density values increased with the soil depth in all land use systems except in the cocoa plantation.

The surface soil $(0-10 \mathrm{~cm})$ in the cocoa plantation showed a very similar bulk density to that of the immediate subsoil $(10-20 \mathrm{~cm})$. 


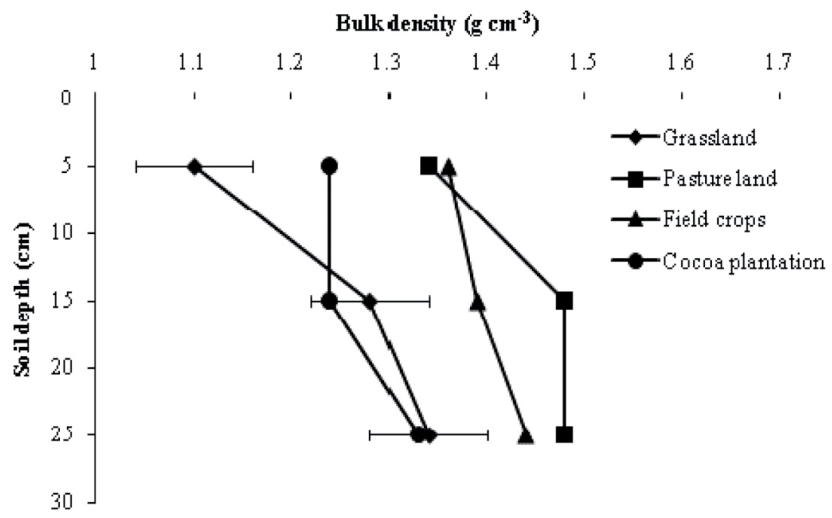

Figure 2. Variability in the bulk density with the soil depth under different land use systems. The error bars indicate the standard error values.

3.2. Effect of land use systems and soil depth on the soil C fractions

The soil inorganic carbon (SIC) concentrations did not vary significantly $(\mathrm{P}>0.05)$ in the land use systems (Table 2). The soil organic carbon (SOC) concentrations differed significantly $(\mathrm{P}<0.001)$ among the land use systems. A remarkable decline in the organic $\mathrm{C}$ concentration of the grasslands was observed in the topsoil $(0-10 \mathrm{~cm})$ of the field crops and cocoa plantation. In the land use profiles, the organic $\mathrm{C}$ concentration decreased with the depth, except under the field crops.

Table 2. Influence of the land use systems and soil depth on the distribution of the soil $\mathrm{C}$ fractions

\begin{tabular}{|c|c|c|c|c|}
\hline Land use & Soil depth $(\mathrm{cm})$ & $\begin{array}{l}\text { Soil inorganic carbon ( } \mathrm{g} \\
\mathrm{kg}^{-1} \text { ) }\end{array}$ & $\begin{array}{l}\text { Soil organic carbon ( } \mathrm{g} \\
\left.\mathrm{kg}^{-1}\right)\end{array}$ & Total carbon $\left(\mathrm{g} \mathrm{kg}^{-1}\right)$ \\
\hline \multirow{3}{*}{ Grassland } & $0-10$ & 14.28 & $81.81^{\mathrm{a}}$ & $96.09^{\mathrm{a}}$ \\
\hline & $10-20$ & 10.27 & $60.2 \mathrm{l}^{\mathrm{abc}}$ & $70.48^{\mathrm{bcd}}$ \\
\hline & $20-30$ & 8.22 & $48.69^{\circ}$ & $56.91^{\mathrm{d}}$ \\
\hline \multirow[t]{3}{*}{ Pasture land } & $0-10$ & 13.54 & $75.73^{\mathrm{ab}}$ & $89.27^{\mathrm{ab}}$ \\
\hline & $10-20$ & 10.56 & $73.87^{\mathrm{ab}}$ & $84.43^{\text {abc }}$ \\
\hline & $20-30$ & 9.06 & $58.04^{\mathrm{abc}}$ & $67.10^{\text {bcd }}$ \\
\hline \multirow[t]{3}{*}{ Field crops } & $0-10$ & 10.79 & $42.72^{\circ}$ & $53.51^{\mathrm{d}}$ \\
\hline & $10-20$ & 12.58 & $40.55^{\mathrm{c}}$ & $53.13^{\mathrm{d}}$ \\
\hline & $20-30$ & 12.02 & $48.37^{\mathrm{c}}$ & $60.39^{\text {cd }}$ \\
\hline \multirow[t]{3}{*}{ Cocoa plantation } & $0-10$ & 11.91 & $57.00^{\mathrm{bc}}$ & $68.90^{\text {bod }}$ \\
\hline & $10-20$ & 14.80 & $43.16^{\mathrm{c}}$ & $57.96^{\mathrm{d}}$ \\
\hline & $20-30$ & 12.39 & $39.26^{\mathrm{c}}$ & $51.63^{\mathrm{d}}$ \\
\hline \multicolumn{5}{|l|}{$P$ value } \\
\hline Land use & & 0.653 & 0.002 & 0.005 \\
\hline Soil depth & & 0.373 & 0.041 & 0.023 \\
\hline $\begin{array}{l}\text { Land use X soil } \\
\text { depth }\end{array}$ & & 0.560 & 0.386 & 0.261 \\
\hline LSD value & & 6.62 & 24.21 & 24.85 \\
\hline
\end{tabular}

The mean values with different letters are significantly different 
The depth wise distribution of the total C concentration in the various land use systems was similar to that of the organic $\mathrm{C}$ concentration. The highest total $\mathrm{C}$ content was in the topsoils $(0-10 \mathrm{~cm})$ of the grassland $\left(96.1 \mathrm{~g} \mathrm{~kg}^{-1}\right)$, which decreased significantly by $28 \%$ in the cocoa plantation $\left(68.9 \mathrm{mg} \mathrm{kg}^{-1}\right)$ and $44 \%$ in the soils under the field crops $\left(53.5 \mathrm{mg} \mathrm{kg}^{-1}\right)$. A strong positive correlation existed between the SOC and total $\mathrm{C}$ content $(\mathrm{r}=0.981 ; \mathrm{p}=0.0001)$, which indicates that a major portion of the total $\mathrm{C}$ originated from the organic $\mathrm{C}$ in the soils. The relationships between the SIC and total $\mathrm{C}(\mathrm{r}=0.152 ; \mathrm{P}=0.382)$ and the SIC and SOC $(r=-0.043 ; P=0.804)$ were weak. The results indicate that SOC could be a proxy to the total C content of the soil. The minimal variations in the SIC across the land use systems suggest the limited value of the SIC evaluation as a measure of land use change.

\subsection{Effect of the land use conversion on the soil C stocks}

The inorganic $\mathrm{C}$ stocks under the studied land use sys tems were similar $(\mathrm{P}>0.05)$, and the stocks ranged from 32.8 to $39.1 \mathrm{Mg} \mathrm{ha}^{-1}$ (Table 3 ). The soil organic carbon stocks were significantly different among the land use systems. The conversion of grassland into another land use system triggered a decline in the soil organic C stock. The SOC stocks were present in the following order: grassland (217.9 $\left.\mathrm{Mg} \mathrm{ha}^{-1}\right)>$ pasture $(207.6 \mathrm{Mg}$ $\left.\mathrm{ha}^{-1}\right)>$ cocoa plantation $\left(139.4 \mathrm{Mg} \mathrm{ha}^{-1}\right)>$ field crops $\left(131.6 \mathrm{Mg} \mathrm{ha}^{-1}\right)$. The total soil organic $\mathrm{C}$ showed a similar trend to that of the organic $\mathrm{C}$ stock among the land use systems. Among all land use systems, the organic C stock was the dominant pool (78.1-86.9\%) compared to the inorganic $\mathrm{C}$ pool, which contributed $13.1 \%-21.9 \%$ to the total $\mathrm{C}$ stock. The conversion of the tropical grassland into an agroforestry system with cocoa trees significantly $(\mathrm{P}<0.05)$ decreased the organic $\mathrm{C}$ and total $\mathrm{C}$ stocks in the soil. The soils under the field crops had the least reserves of organic $\mathrm{C}$, with a depletion rate of $2271 \mathrm{~kg} \mathrm{C} \mathrm{ha}^{-1} \mathrm{yr}^{-1}$.

Table 3. Magnitude of the soil $\mathrm{C}$ fractions and the rate of soil organic $\mathrm{C}$ change in the different land use systems over 28 years

\begin{tabular}{lcccc}
\hline Land use & $\begin{array}{c}\text { Inorganic C stock } \\
\left(\mathrm{Mg} \mathrm{ha}^{-1}\right)\end{array}$ & $\begin{array}{c}\text { Organic C stock } \\
\left(\mathrm{Mg} \mathrm{ha}^{-1}\right)\end{array}$ & $\begin{array}{c}\text { Total C stock } \\
\left(\mathrm{Mg} \mathrm{ha}^{-1}\right)\end{array}$ & $\begin{array}{c}\text { Rate of organic C } \\
\text { depletion } \\
\left(\mathrm{kg} \mathrm{ha}^{-1} \mathrm{yr}^{-1}\right)\end{array}$ \\
\hline Grassland & $32.8^{\mathrm{a}}(13.1 \%)^{\mathrm{a}}$ & $217.9^{\mathrm{a}}(86.9 \%)$ & $250.7^{\mathrm{a}}$ & - \\
Pasture land & $33.2^{\mathrm{a}}(13.8 \%)$ & $207.6^{\mathrm{a}}(86.2 \%)$ & $240.8^{\mathrm{ab}}$ & $-271^{\mathrm{b}}$ \\
Field crops & $35.3^{\mathrm{a}}(21.1 \%)$ & $131.6^{\mathrm{b}}(78.9 \%)$ & $167.0^{\mathrm{c}}$ & $-2271^{\mathrm{a}}$ \\
Cocoa plantation & $39.1^{\mathrm{a}}(21.9 \%)$ & $139.4^{\mathrm{b}}(78.1 \%)$ & $178.5^{\mathrm{bc}}$ & $-2066^{\mathrm{a}}$ \\
\hline$P$ value & 0.631 & 0.032 & 0.048 & 0.038 \\
\hline
\end{tabular}

The mean values followed with different letters are significantly different. $\ddagger$ The figures in parenthesis are the contribution percentage to the total $\mathrm{C}$ stock 


\section{Discussion}

The soil bulk density is an important parameter for characterizing the physical health of soil and assessing the SOC contents. Physical properties such as the bulk density, compression strength and pore volume can be affected by different land use systems (Fleige et al., 2016). Continuous animal movement and trampling actions can result in the soil compaction in livestock grazing areas (Gebremariam and Kebede, 2010). The greater bulk density values under the field crops were attributed to heavy farm-tool traffic from tractors and plow tillage operations. Frequent plow tillage practices break the soil aggregates and disturb the soil structural characteristics. Thus, over the years, the soils tend to show structural deterioration leading to increased bulk density and compaction (Kizilkaya and Dengiz, 2010). The bulk density values normally increased with the soil depth among the land use systems.

The similar SIC values among the different land use systems indicate that the SIC contribution was predominantly geogenic or pedogenic, and the SIC concentrations were minimally related to the land use systems. Land use patterns can only affect the SIC in the long term (Saurez, 2006). A decrease in the SIC concentration with the profile depth was observed in all land profiles, except under the field crops. In humid environments, the major anthropogenic impacts on the SIC concentrations include surface soil liming, the use of ammonia vs. nitrate fertilizers, and the removal of vegetation and erosion (Saurez, 2006). A negative correlation between the SOC content and sampling depth was reported by Aticho (2013) in Kafa, Southwest Ethiopia. Under the field crops, frequent plow tillage inverted the surface organic matter and possibly enriched the organic $\mathrm{C}$ content of the $20-30 \mathrm{~cm}$ soil. In the absence of fresh organic carbon inputs, which are an essential source of energy for soil microbes, the stability of the organic carbon in deep soil layers can be maintained due to the slow mineralization of C (Fontaine et al., 2007). Other numerous mechanisms and drivers of soil $\mathrm{C}$ turnover, such as plants, microorganisms and mineralogical interactions, can influence the emission rates of SOC from subsoil (Merino et al., 2015).

The grasslands showed the highest total soil organic C stock compared to the other land use systems due to the greater ability of grasslands to produce diverse aboveground biomass (Pinheiro et al., 2010) or due to the addition of recalcitrant black $\mathrm{C}$ during burning operations (Goodrick et al., 2015). Natural and restored grasslands are effective vegetation types for SOC sequestration due to the higher carbon input from the roots (Wei et al., 2012). Other studies have shown that grazing intensities and stock rates can either increase (Nair et al., 2009) or decrease soil organic C stocks (Derner et al., 2006) depending on the herbage composition and characteristics of the study site. In the present study, a decline rate of $271 \mathrm{~kg}$ organic ${\mathrm{C} \mathrm{yr}^{-1}}^{-1}$ $\mathrm{ha}^{-1}$ was recorded assuming a linear decay pattern under the grazing system. These results are in agreement with those from a study by Lal (2002) who observed that when other factors remained the same, the grazing land soils had more SOC than the cropland soils, which was attributed to (1) low soil disturbances due to a lack of plowing and (2) more root biomass and residue that returned to the surface.

The observation that the conversion of tropical grasslands into cocoa trees decreased organic $\mathrm{C}$ and total $\mathrm{C}$ stocks is contrary to the general belief that agroforestry systems improve $\mathrm{C}$ stocks. The estimated organic C stock of the 0-30 $\mathrm{cm}$ profile soil was greater than that observed for cocoa+gliricidia (Gliricidia sepium) plantations in Brazil and Indonesia (Berrato et al., 2011). Our estimates of organic $C$ stocks were much less than the values recorded under cocoa+erythrina (Erythrina poeppigiana) plantations in Costa Rica (240 Mg ha ${ }^{-1}, 0-45 \mathrm{~cm}$ depth) (Berrato et al., 2011). 
The conversion of a grassland site into a cocoa system resulted in the net loss of soil organic $\mathrm{C}$ at a rate of $2066 \mathrm{~kg} \mathrm{C} \mathrm{ha}^{-1} \mathrm{yr}^{-1}$. Leuschner et al. (2013) reported a $70-80 \%$ reduced $\mathrm{C}$ sequestration potential in soils due to the smaller aerial biomass production increments in cocoa species compared to grassland vegetation species. The lowest organic $\mathrm{C}$ reserves in the field crop lands were attributed to repeated plow tillage operations during land preparation. These operations could have improved soil aeration leading to the enhanced microbial and chemical oxidation of antecedent $\mathrm{C}$ stocks (Potthoff et al., 2005; Conant et al., 2007; Melero et al., 2009). The infrequent organic matter inputs could also be the reason for the inability to maintain $\mathrm{C}$ stocks at antecedent levels under a field crop regime.

\section{Conclusions}

The results of the study indicated that the conversion of grassland sites into other land use systems leads to the depletion of $\mathrm{C}$ stocks. The greatest $\mathrm{C}$ losses were recorded under field crops, while pastures showed a greater potential to retain $\mathrm{C}$ stocks. The use of pasture systems with improved livestock grazing and appropriate pastoral management practices could negate the small $\mathrm{C}$ losses. Under field crops, agronomic practices such as minimum tillage can be explored to offset the hefty $\mathrm{C}$ losses. Large-scale land use changes are often unavoidable, especially in developing countries, due to socio-economic and political drivers. From an ecological perspective, the conversion of grassland systems into pasture systems is a preferred option due to the minimum $\mathrm{C}$ emissions from the soil in the latter system. The soil organic $\mathrm{C}$ content and stocks are unquestionably important indices of the soil fertility and quality and the sustainability of soil management practices. Therefore, the results of the current study highlight the need for improving soil management strategies to counteract the $\mathrm{C}$ depletion in field crops and cocoa plantations developed from grasslands.

\section{Acknowledgements}

The authors would like to thank the Department of Agriculture and Unitech Analytical Services Laboratories for allowing the use of their analytical facilities.

\section{References}

Aticho, A. 2013. Evaluating organic carbon storage capacity of forest soil: case study in Kafa Zone Bita District, Southwestern Ethiopia. AmericanEurasian J. Agric. Environ. Sci. 13, 95-100.

Berreto, P.A.B., Gama-Rodrigues, E.F., Gama-Rodrigues, A.C., Fontes, A.G., Polidoro, J.C., Moco, M.K.S., Machado, R.C.R., Baligar, V.C. 2011. Distribution of oxidisable organic $\mathrm{C}$ fractions in soils under cacao agroforestry system in Southern Bahia, Brazil. Agroforest. Syst. 81, 213-220.

Blake, G.R., Hartge, K.R. 1986. Bulk Density. In: A. Klute (eds). Methods of Soil Analysis, Part 1: Physical and Mineralogical Methods, Second Edition. Soil Science Society of America, Madison, WI, pp: 363-375.

Conant, R.T., Easter, M., Paustian, K., Swan, A., Williams, S. 2007. Impact of periodic tillage on soil C stock: A synthesis. Soil Tillage Res. 95, 1-10.

Derner, J., Boutton, T., Briske, D. 2006. Grazing and ecosystem carbon storage in the North American Great Plains. Plant Soil. 280, 77-90.

Fleige, H., Beck-Broichsitter, S., Dorner, J., Goebel, M.O., Bachmann, J., Horn, R. 2016. Land use and soil development in southern Chile: Effects on physical properties. J. Soil Sci. Plant Nutr. 16, 818-831.

Fontaine, S., Barot, S., Barre, P., Bdioui, N., Mary, B., Rumpel, C. 2007. Stability of organic carbon in deep soil layers controlled by fresh carbon supply. Nature. 450, 277-280. 
Franzluebbers, A.J., Arshad, M.A. 1996. Soil organic matter pools during early adoption of conservation tillage in northwestern Canada. Soil Sci. Soc. Am. J. 60, 1422-1427.

Gama-Rodrigues, E.F., Nair, P.K.R., Nair, V.D., Gama-Rodrigues, A.C., Baligar, V.C., Machado, R.C.R. 2010. Carbon storage in soil size fractions under two cacao agroforestry systems in Bahia, Brazil. Environ. Manage. 45, 274-283.

Gebremariam, M., Kebede, F. 2010. Land use change effect on soil carbon stock, above ground biomass, aggregate stability and soil Crust: A case from Tahtay Adyabo, North Western Tigray, Northern Ethiopia. J. Drylands. 3, 220-225.

Gelaw, M.A., Singh, B.R., Lal, R. 2014. Soil organic carbon and total nitrogen stocks under different land uses in a semi-arid watershed in Tigray, Northern Ethiopia. Agric. Ecosyst. Environ. 188, 256-263.

Goodrick, I., Nelson, P.N., Banabas, M., Wurster, C.M., Bird, M.I. 2015. Soil carbon balance following conversion of grassland to oil palm. GCB Bioenergy. 7, 263-272.

Grandy, A.S., Robertson, G.P. 2007. Land-use intensity effects on soil organic carbon accumulation rates and mechanisms. Ecosystems. 10, 59-74.

Hairiah, K., Dewi, S., Agus, F., Velarde, S., Ekadinata, A., Rahayu, S., van Noordwijk, M. 2010. Measuring Carbon Stocks Across Land Use Systems: A Manual. World Agroforestry Centre (ICRAF), SEA Regional Office, Bogor, Indonesia, 155 p.

Hartemink, A.E., Poloma, S., Maino, M., Powell, K.S., Egenae, J., O'Sullivan, J.N. 2000. Yield decline of sweet potato in the humid lowlands of Papua New Guinea. Agric. Ecosyst. Environ. 79, 259-269.

IPCC. 2013. Climate Change 2013: The Physical Science Basis. Contribution of Working Group I to the Fifth Assessment Report of the Intergovern- mental Panel on Climate Change [Stocker, T.F., D. Qin, G.-K. Plattner, M. Tignor, S.K. Allen, J. Boschung, A. Nauels, Y. Xia, V. Bex and P.M. Midgley (Eds.)]. Cambridge University Press, Cambridge, United Kingdom and New York, NY, USA, 1535 p.

Kizilkaya, R., Dengiz, O. 2010. Variation of land use and land cover effects on some soil physicochemical charecteristics and soil enzyme activity. Zemdirbyste-Agric. 97, 15-24.

Kumar, M. B., Nair, P.K.R. 2011. Carbon Sequestration Potential of Agroforestry Systems Opportunities and Challenges. Springer, The Netherlands, $310 \mathrm{p}$.

Lal, R. 2002. Soil carbon dynamics in cropland and rangeland. Environ. Pollut. 116, 353-362.

Lal, R. 2004. Soil carbon sequestration impacts on global climate change and food security. Science. 304, 1623-1627.

Leuschner, C., Moser, G., Hertel, D., Erasmi, S., Leitner, D., Culmsee, H., Schuldt, B., Schwendenmann, L. 2013. Conversion of tropical moist forest into cacao agroforest: consequences for carbon pools and annual C sequestration Agroforest. Syst. 87, 1173-1187.

Maraseni, T.N., Mathers, N.J., Harms, B., Cockfield, G., Apan, A., Maroulis, J. 2008. Comparing and predicting soil carbon quantities under different land-use systems on the Red Ferrosol soils of southeast Queensland. J. Soil Water Conserv. 63, 250-256.

Melero, S., Lopez-Garrido, R., Murillo, J.M., Moreno, F. 2009. Conservation tillage: short- and longterm effects on soil carbon fractions and enzymatic activities under Mediterranean conditions. Soil Till. Res. 104, 292-298.

Merino, C., Nannipieri, P., Matus, F., 2015. Soil carbon controlled by plant, microorganism and mineralogy interactions. J. Soil Sci. Plant Nutri. 15, 321-332. 
Munoz, C., Cruz, B., Rojo, F., Campos, J., Casanova, M., Doetterl, S., Boeckx, P., Zagal, E. 2016. Temperature sensitivity of carbon decomposition in soil aggregates along a climatic gradient. J. Soil Sci. 16, 461-476.

Nair, P.K., Kumar, B., Nair, V.D. 2009. Agroforestry as a strategy for carbon sequestration. J. Soil Sci. Plant Nut. 172, 10-23.

Potthoff, M., Jackson, L.E., Steenwerth, K.L., Ramirez, I., Stromberg, M.R., Rolston, D.E. 2005. Soil biological and chemical properties in restored perennial grassland in California. Restoration Ecol. 13, 61-73.

Pinheiro, E.F.M., Lima, E., Ceddia, M.B., Urquiaga, S., Alves, B.J.R. 2010. Impact of pre-harvest burning versus trash conservation on soil carbon and nitrogen stocks on a sugarcane plantation in the Brazilian Atlantic forest region. Plant Soil. $333,71-80$

Rumpel, C., Crème, A., Ngo, P.T., Velásquez, G., Mora, M., Chabbi, A. 2015. The impact of grassland management on biogeochemical cycles involving carbon, nitrogen and phosphorous. J. Soil Sci. Plant Nutri. 15, 353-371.
Saurez, D.L. 2006. Inorganic carbon: Land use impacts. In: Encyclopaedia of soil science volume 1. (Ed. Lal, R.). CRC Press, New York, USA. pp. 895-897.

Shearman, P.L., Ash, J., Mackey, B., Bryan, J.E., Lokes, B. 2009. Forest conversion and degradation in Papua New Guinea 1972-2002. Biotropica. 41, 379-390.

Smith, P., House, I.J., Bustamante, M., Sobocka, J., Harper, R., Pan, G., West, P.C., Clark, J.M., Adhya, T., Rumpel, C., Paustian, K., Kuikman, P., Cotrufo, M.F., Elliott, J.A., McDowell, R., Groffiths, R.I., Asakawa, S., Bondeau, A., Jain, A.K., Meersmans, J., Pugh, T.A.M. 2016. Global change pressures on soils from land use and management. Global Change Biology. 22, 1008-1028.

Wang, X., Wang, J., Zhang, J. 2012. Comparisons of three methods for organic and inorganic carbon in calcareous soils of Northwestern China. PLOS one. DOI: 10.1371/journal.pone.0044334 